\title{
Technological Innovations in New Type Coronavirus and Health System
}

\author{
Yeni Tip Koronavirüs ve Sağlık Sistemindeki Teknolojik Yenilikler
}

(D) Yasemin GÜNER1, iD Elif KILIÇ GÜNER², iD Dilek ÇILINGİं³

${ }^{1}$ Karadeniz Technical Univeristy, Faculty of Medical Science, Department of Medical Education, Trabzon, Turkey

2Karadeniz Technical University Farabi Hospital, Education Coordinator, Trabzon, Turkey

${ }^{3}$ Karadeniz Technical University Faculty of Health Sciences, Department of Surgical Nursing, Trabzon, Turkey

\begin{abstract}
The new type of Coronavirus disease-19 (COVID-19) spreads rapidly as a global epidemic and affects health, economic and social systems. Increasing the number of patients in COVID-19 hospitals negatively affects the health system by causing insufficient materials and health workers to be exposed to the risk of infection. Ethical dilemmas regarding providing healthcare to all patients are more difficult due to uncertainties caused by the disease, change in social life, stress, emotional deterioration, having to work for a long time, insufficient intensive care conditions and mechanical ventilation during the pandemic period. In this process, new and creative approaches are needed in the health system to effectively meet the health needs of individuals. Telemedicine applications, mobile applications, web-based applications and psychological support applications are among these approaches. In this paper, a new type of COVID-19 pandemic in the world and Turkey was referred to the process of innovation in the health care system.
\end{abstract}

Keywords: Coronavirus, innovation, health system

\section{ÖZ}

Yeni tip koronavirüsün (COVID-19), küresel bir pandemi olarak hızla yayılmakta olup sağlık, ekonomik ve sosyal sistemleri etkilediği görülmektedir. COVID-19 hastanelerdeki hasta sayısının artması, malzeme yetersizliği ve sağlık çalışanlarının enfeksiyon riskine maruz kalmasına neden olarak sağlık sistemini olumsuz yönde etkilemektedir. Pandemi döneminde hastalığın neden olduğu belirsizlikler, sosyal yaşamdaki değişim, stres, duygusal çöküntü, uzun süre çalışmak zorunda kalma, yetersiz yoğun bakım şartları ve mekanik ventilatör nedeniyle tüm hastalara gereken sağlı hizmetini vermeye ilişkin etik ikilemler, bu süreci daha güç hale getirmektedir. $\mathrm{Bu}$ süreçte bireylerin sağlık bakım gereksinimlerinin etkin şekilde karşılanması için, sağlık bakım sisteminde yeni ve yaratıcı yaklaşımlara gereksinim duyulmaktadır. Teletıp uygulamaları, mobil uygulamalar, web tabanlı uygulamalar ve psikolojik destek uygulamaları bu yaklaşımlar arasında yer almaktadır. Bu derlemede, dünyada ve Türkiye'de COVİD-19 pandemi sürecinde sağlık sistemlerinde yapılan yeniliklere değinildi.

Anahtar Sözcükler: Koronavirüs, inovasyon, sağlık sistemi

\section{Introduction}

In December 2019, a new type of coronavirus, which is rapidly transmitted from person to person and has a high mortality, emerged in Wuhan, China. Today, there is no special antiviral treatment and vaccine to protect against the new type of Coronavirus disease-19 (COVID-19). This situation negatively affected the health systems of all countries in the world (1-5); the high numbers of patients experienced in hospitals caused disruption or postponement of outpatient, diagnostic and surgical procedures. At the same time, the new type of coronavirus pandemic process has led to changes and improvements in the health systems of countries (6). During the pandemic period, especially since the lack of some innovations in the health system, new and creative 
approaches were needed and it was revealed that innovation was critical in the health system (7-9). Therefore, countries have tried to face the pandemic by developing their digital infrastructure and engineering capabilities. In addition, the spread of COVID-19 has been tried to be mitigated by developing action plans with technologies that provide community-driven and communication tracking and by implementing some practices $(10,11)$. In this review, we aimed to address the innovation made in the health care systems in the world and in Turkey during the new type of coronavirus pandemic period.

\section{New Type of Coronavirus (COVID-19)}

Coronaviruses are single-stranded RNA viruses that mostly infect birds and mammals and belong to the coronaviridae family. These viruses have been seen in humans as SARS (Severe Acute Respiratory Syndrome) and MERS (Middle East Respiratory Syndrome) disease $(1,12,13)$. Today, a new coronavirus has been found that infects humans. The virus is expressed with the word "corona", which means crown in Latin, and named temporarily "2019-nCoV" and updated to COVID-19 as of February 12, $2020(2,3)$. This virus can be transmitted rapidly from person to person through droplets and contact $(1,14)$. Coronavirus causes symptoms such as fever, cough, dyspnea, fatigue, nausea, vomiting and diarrhea in humans. In severe cases, dyspnea, severe acute respiratory tract infection, kidney failure and pneumonia are seen. Death may occur depending on the progression of the disease $(1,4)$.

\section{Effect of COVID-19 on Health System}

COVID-19 spread among people in a short period of time and affected the whole world and was classified as a pandemic by the World Health Organization (WHO). Until now, the total number of cases in the world has been reported as 8,349,972 and the total number of deaths as 448,962 (15). This indicates that the virus is rapidly transmitted and its mortality is high. Although there is no vaccine and specific treatment developed so far to prevent COVID-19, studies continue in many countries $(1,4,5,16)$. The increase in patient numbers in hospitals due to COVID-19 has led to the disruption of the outpatient clinic services and other services provided to the patients and the delay of the surgeries (16). Countries have implemented emergency action plans by developing various strategies in order to solve the problems experienced in their health systems, to isolate suspicious cases and to prevent the spread of the disease $(5,16)$. The precautions included in these action plans and these required to be implemented are non-pharmacological public health measures such as isolation, social distance and quarantine. Isolation includes segregation of symptomatic patients, and quarantine includes restriction of asymptomatic healthy individuals who have come into contact with confirmed or suspected cases. Quarantine can be applied on a voluntary basis or legally by the authorities at the individual, group or community level. These methods are known as the most effective way to respond to the pandemic $(14,17)$. In addition, countries have followed the guidelines and recommendations put forward by global institutions (such as CDC, WHO) in health systems.
Strict implementation of these measures is essential to reduce the spread of disease and prevent health system collapse. However, as there are serious gaps in developed economies and health systems, new and creative approaches in health services were required to learn, experience and able to connect during the pandemic $(7,8,14)$. These new and creative approaches are listed below.

\section{Telemedicine Applications}

Telemedicine applications, which have a recent history in health care systems, started to be used more in the COVID-19 pandemic period. These web-based applications, in which electronic patient records are used to reduce the number of individuals applying for health services, are called "telemedicine". Telemedicine is a system that allows physicians and patients to communicate $24 / 7$ using smart phones or computers and includes classification before they come to the emergency room. In addition, telemedicine is a system that was made available to all primary care patients in the healthcare system during the COVID-19 pandemic, and patients are guided according to whether they have symptoms of COVID-19. If the individual is asymptomatic, the presence of contact history with any known case is questioned and information is given about COVID-19 disease. If the individual is symptomatic, patients are divided into four categories (requiring urgent intervention, urgent, nonurgent or self-sufficient) and connected to the COVID-19 unit via telephone after planning. Respiratory symptoms that may be early signs of COVID-19, travel and contact histories of patients are among the most frequently evaluated conditions with this approach. Thus, the density in hospitals can be prevented, and the exposure of healthcare workers to COVID-19 is reduced. Another example of telemedicine applications is the "JeffConnect" application. Patients can access this system with their user names and passwords via their mobile phone or computer system. In the system, the patient first fills in his personal information (location, phone number, nearest pharmacy, height, weight, etc.), and then information about his current illness (symptoms such as allergies, cough, constipation, diarrhea, etc.). Depending on the patient's complaint, the physician prescribes medication or gives information about the disease. With this system, physicians and healthcare professionals can provide consultancy services to patients who experience COVID-19 symptoms at any time via a mobile phone/tablet or a computer with a webcam. In addition, with this system, when patients with suspected COVID-19 need to be tested, central coordination can be achieved with healthcare personnel as well as local test institutions (18-21).

For telemedicine applications in our country, "ALO 184 Corona Information Line" (SABİM) has started to serve. With this application, individuals are guided by obtaining information from specialist physicians in case of COVID-19 symptoms (22). All of these applications have been developed to prevent unnecessary hospital applications during the pandemic by making the triage system more effective. These methods are patient-centered, convenient for individuals to self-quarantine and reduce the virus burden of healthcare workers. 


\section{Mobile Applications}

Another technology developed during the COVID-19 pandemic is mobile applications. "TraceTogether" and "Coronavirus Pandemic Epidemiology (COPE)" are some of these applications. With these mobile applications, it provides many data such as demographic and clinical information of individuals, symptoms, test results, quarantine tracking of infected individuals and accessing the contact history of an infected individual and a healthy individual. In addition, applications provide guidelines for individuals regarding coronavirus disease, transmission routes, online screening tool, testing or situations requiring emergency intervention (23-27).

In Turkey, with the scope of COVID-19 combat, the Ministry of Health developed a mobile application named "Hayat Eve Sığar-HES", in which citizens can follow the risks and health conditions. In the HES application, individuals fill out the questionnaire regarding their own health status and can easily access the latest developments regarding the virus, the risk map of their location, the closest health institution, pharmacy, market chain, metro and stations. This practice aims to minimize the risks associated with the epidemic that may be experienced and to prevent its spread (28).

Another application developed by the Ministry of Health is the "Korona Önlem" application. With this application, the risk status of the individual is calculated as a result of inquiries about identity information, personal information, chronic diseases, travel history and complaints, and guidance is made (29).

\section{Web-based Applications}

Web-based maps were created to facilitate the tracking of the virus during the COVID-19 pandemic period. The map "Coronaviz.umiacs.io" is one of the web based maps. This application was developed in order to predict the emergence of the virus in new regions and to make countries more ready for the epidemic process (30). In this way, the regional spread of the virus can be seen in the world. In China, Lian Fei Technology has established a blockchain platform, providing up-to-date case numbers in the COVID-19 pandemic, ensuring the clarity of information, transparency and traceability of developments $(31,32)$. In addition, the Global MediXchange platform, developed by the Alibaba cloud and Jack Ma Foundation, made available the studies on the subject using information and artificial intelligence technology and shared them with healthcare professionals around the world. In this way, online communication and cooperation between countries has been facilitated and experiences experienced during the pandemic process are shared with other countries in the world (33).

In our country, there are web-based applications within the scope of coronavirus studies. TUBITAK and Ministry of Industry and Technology together, in cooperation, implemented "COVID-19 Turkey Web Portal" and COVID-19 Pandemic Follow-up Display (TURCOVID19)", applications, which are among these web-based applications. In COVID-19 Turkey Web Portal, COVID-19 cases of instant availability and data are shared taht were gained by researchers engaged in research on the subject in Turkey and in the World, whereas in Turkey COVID-19 Pandemic Follow-Up Display (TURCOVID19) application, information about the cases of death and improving patient numbers, applied to the number of tests, the data in the case-fatality rate (VÖO), intensive care admission and intubated patient categories are shared with the public daily and visually $(34,35)$.

\section{Psychological Support Practices}

Countries that anticipate that psychological side effects (fear, panic in the society) that develop due to isolation during the pandemic process may cause more harm than COVID-19 have attached importance to protecting the mental health of the society. Therefore, applications such as text messaging, chat, telephone, video conferencing, websites, mobile applications, online self-help platform and online group chat have been developed (36). With these practices, it was aimed to support societies by enabling individuals to cope more easily with feelings of fear, panic and helplessness in the face of uncertainty (37). In our country, "Corona Psychosocial Support Line" and "Corona Information and Counseling Line" have been put into practice to provide psychological counseling (38).

\section{Other Developed Applications}

In addition to the applications mentioned above, different applications have also come up. Home evaluation teams, virtual maintenance centers and $3 \mathrm{D}$ printers that produce equipment are some of them. The home evaluation team has been set up to provide real-time clinical assessments of patients who do not require emergency medical care or hospitalization. This model facilitated access to the COVID-19 test for patients, reducing complexity, and benefiting the health system by increasing safety and efficiency (39). In order to conduct a similar filiation/field examination in our country, an expert team has been formed to screen the relatives/contacts of positive cases. The filiation / field investigation team aimed to work on the determination of the source and the agent and to increase protection and control measures, including those who had contact with the virus (40). Another application is virtual care centers. This application includes an electronic intensive care unit monitoring program that allows nurses and physicians to remotely monitor the status of 60 to 100 patients hospitalized in the intensive care units of more than one hospital. This practice is an application that reduces the contact of healthcare professionals with infected patients in the intensive care unit (7). Another application is 3D printers that produce equipment. During the pandemic process, an innovative technology, three-dimensional (3D) printer, was used to ensure adequate production and distribution of medical products due to the limited number of N95 respirators, face shields, ventilator valves, test kits and other individual protective equipment $(41,42)$. This new technology has enabled healthcare workers at the forefront of my pandemic to be provided with adequate equipment and vital products for patients. 
As a result, it is seen that technology is used effectively in the COVID-19 pandemic process. Telemedicine, mobile and web applications are among the applications that enter our lives actively in this process. The use of technology has provided benefits in many aspects such as reducing the number of admissions in emergency services and the virus load of healthcare personnel, monitoring patients at home, protecting the mental health of the community, producing sufficient equipment and facilitating access to academic studies. It is thought that the innovations brought by technology to our lives during and after the COVID-19 process will be permanent. However, it is thought that these practices may have deficiencies such as the inability of health professionals to perform physical examinations, being based on the patient's statement, not necessarily using the applications, having difficulties in accessing technological infrastructure, and individuals not being able to use technology. Therefore, it is recommended to conduct studies evaluating the positive and negative aspects of these applications, and their effectiveness on patients and healthcare professionals.

Peer-review: Externally peer reviewed.

\section{Authorship Contributions}

Concept: Y.G., E.K.G., D.Ç., Design: Y.G., E.K.G., D.Ç., Data Collection or Processing: Y.G., E.K.G., D.Ç., Analysis or Interpretation: Y.G., E.K.G., D.Ç., Literature Search: Y.G., E.K.G., D.Ç., Writing: Y.G., E.K.G., D.Ç.

Conflict of Interest: No conflict of interest was declared by the authors.

Financial Disclosure: This work was supported by Gilead Sciences.

\section{References}

1. Liu YC, Kuo RL, Shih SR. COVID-19: The first documented coronavirus pandemic in history. Biomed J 2020;43:328-33.

2. T.C. Sağlık Bakanlığı. COVID-19 (SARS-CoV2 Enfeksiyonu) Rehberi. Last Accessed Date: 18.05.2020. Available from: https:// covid19bilgi.saglik.gov.tr/depo/rehberler/COVID-19_Rehberi.pdf.

3. World Health Organization. Q\&A on coronaviruses (COVID-19). Last Accessed Date: 03.05.2020. Available from: https://www.who. int/emergencies/diseases/novel-coronavirus-2019/question-andanswers-hub/q-a-detail/coronavirus-disease-covid-19.

4. Mercantini P, Lucarini A, Mazzuca F, Osti MF, Laghi A. How technology can help in oncologic patient management during COVID-19 outbreak. Eur J Surg Oncol 2020;46:1189-91.

5. Hantoushzadeh S, Norooznezhad AH. Possible cause of inflammatory storm and septic shock in patients diagnosed with (COVID-19). Arch Med Res 2020;51:347-8.

6. Ahmed SF, Quadeer AA, McKay MR. Preliminary identification of potential vaccine targets for the COVID-19 coronavirus (SARSCoV-2) based on SARS-CoV immunological studies. Viruses 2020;12:254.

7. Reeves JJ, Hollandsworth HM, Torriani FJ, Taplitz R, Abeles S, TaiSeale M, et al. Rapid response to COVID-19: health informatics support for outbreak management in an academic health system. J Am Med Inform Assoc 2020;27:853-9.

8. Dzau VJ, Yoediono Z, Ellaissi WF, Cho AH. Fostering innovation in medicine and health care: what must academic health centers do? Acad Med 2013;88:1424-9.

9. Goldschmidt K. The COVID-19 pandemic: Technology use to support the wellbeing of children. J Pediatr Nurs 2020;53:88-90.

10. Drew DA, Nguyen LH, Steves CJ, Menni C, Freydin M, Varsavsky $\mathrm{T}$, et al. Rapid implementation of mobile technology for real-time epidemiology of COVID-19. Science 2020;368:1362-7.

11. Ishack S, Lipner SR. Applications of 3D printing technology to address COVID-19-related supply shortages. Am J Med 2020;133:771-3.

12. World Health Organization. Coronavirus disease (COVID-19) pandemic. Last Accessed Date: 14.05.2020. Available from: https:// www.who.int/emergencies/diseases/novel-coronavirus-2019?gclid=C j0KCQjw2PP1BRCiARIsAEqv.

13. Huang C, Wang Y, Li X, Ren L, Zhao J, Hu Y, et al. Clinical features of patients infected with 2019 novel coronavirus in Wuhan, China. Lancet 2020;395:497-506.

14. Nussbaumer-Streit B, Mayr V, Dobrescu AI, Chapman A, Persad E, Klerings I, et al. Quarantine alone or in combination with other public health measures to control COVID-19: A rapid review. Cochrane Database Syst Rev 2020;4:CD013574.

15. COVID-19 Map. The Johns Hopkins Coronavirus Resource Center. Last Accessed Date: 18.06.2020. Available from: https://coronavirus. jhu.edu/map.html.

16. Gunner CK, Oliphant R, Watson AJM. Crises drive innovation. Colorectal Dis 2020;22:1195.

17. Cetron M, Landwirth J. Public health and ethical considerations in planning for quarantine. Yale J Biol Med 2005;78:329-34.

18. Jefferson Health. Coronavirus (COVID-19). Last Accessed Date: 11.05.2020. Available from: https://www.jeffersonhealth.org/ coronavirus-covid-19.html.

19. Hollander JE, Carr BG. Virtually perfect? Telemedicine for Covid-19. N Engl J Med 2020;382:1679-81.

20. Judson TJ, Odisho AY, Neinstein AB, Chao J, Williams A, Miller $\mathrm{C}$, et al. Rapid design and implementation of an integrated patient self-triage and self-scheduling tool for COVID-19. J Am Med Inform Assoc 2020;27:860-6.

21. Jefferson University Hospitals. How to Use JeffConnect ${ }^{\oplus}$. Last Accessed Date: 10.06.2020. Available from: https://hospitals. jefferson.edu/jeffconnect.html.

22. T.C. Sağlık Bakanlığı. Sağlık Bakanı Koca, koronavirüse ilişkin son durumu değerlendirdi. Last Accessed Date: 11.05.2020. Available from: https://www.saglik.gov.tr/TR,64493/saglik-bakani-kocakoronaviruse-iliskin-son-durumu-degerlendirdi.html.

23. Cho H, Ippolito D, Yu YW. Contact tracing mobile apps for COVID-19: Privacy considerations and related trade-offs. Last Accessed Date:11.05.2020. Available from: https:/arxiv.org/ abs/2003.11511.

24. How do I set up the TraceTogether App? - Team TraceTogether. Last Accessed Date: 11.05.2020. Available from: https://tracetogether. 
zendesk.com/hc/en-sg/articles/360043735573-How-do-I-set-upTraceTogether-.

25. Drew DA, Nguyen LH, Steves CJ, Menni C, Freydin M, Varsavsky $\mathrm{T}$, et al. Rapid implementation of mobile technology for real-time epidemiology of COVID-19. Science 2020;368:1362-7.

26. Park S, Choi GJ, Ko H. Information technology-based tracing strategy in response to COVID-19 in South Korea-privacy controversies. JAMA 2020;323:2129-30.

27. Apple releases new COVID-19 app and website based on CDC guidance. Last Accessed Date: 11.05.2020. Available from: https:// www.apple.com/newsroom/2020/03/apple-releases-new-covid-19app-and-website-based-on-CDC-guidance/?subId3=xid:fr 15853349 66948dag.

28. Covid-19 ile mücadelede 'Hayat Eve Sı̆gar' mobil uygulaması hayata geçirildi. Last Accessed Date: 11.05.2020. Available from: https:// www.turkiyegazetesi.com.tr/gundem/697619.aspx.

29. Online "Korona Virüs" kontrolü yapmak ister misiniz? Last Accessed Date: 09.06.2020. Available from: https://koronaonlem.saglik.gov. $\operatorname{tr} /$.

30. Kastner J, Samet H, Wei H. NewsStand CoronaViz: A map query interface for spatio-temporal and spatio-textual monitoring of disease spread. Last Accessed Date: 11.05.2020. Available from: https://arxiv. org/abs/2003.00107.

31. Torky M, Hassanien AE. COVID-19 blockchain framework: Innovative approach. Available from: https://arxiv.org/ abs/2004.06081.

32. Distelmeyer J. Notizen aus dem digitalen Selbstwiderspruch. Rosa Mercedes, 2020:2.

33. Alibabacloud worlwide cloud services partner, 2020. Last Accessed Date: 11.05.2020. Available from: https:/www.alibabacloud.com/ covid-19-global-medixchange.

34. Ahbap. Covid-19 Türkiye Web Portalı. Last Accessed Date: 11.05.2020. Available from: https://covid19.ahbap.org/covid-19turkiye-web-portali/.

35. Uçar A, Arslan Ş, Manap HS, Gürkan T, Çalışkan M, Dayığlu A, et al. An interactive web-based dashboard for Covid-19 pandemic in real-time monitorization in Turkey: TURCOVID19. Anatolian Clinic Journal of Medical Sciences 2020;25(Suppl 1):154-5.

36. Zhou X, Snoswell CL, Harding LE, Bambling M, Edirippulige S, Bai $\mathrm{X}$, Smith AC. The role of telehealth in reducing the mental health burden from COVID-19. Telemed J E Health 2020;26:377-9.

37. Kim CS, Lynch JB, Cohen S, Neme S, Staiger TO, Evans L, et al. One academic health system's early (and ongoing) experience responding to COVID-19: Recommendations from the initial epicenter of the pandemic in the United States. Acad Med 2020;95:1146-8.

38. T.C. Sağlık Bakanlığı. Destek Hat Bilgileri. Last Accessed Date: 11.05.2020. Available from: https://covid19bilgi.saglik.gov.tr/tr/ destek-hat-bilgileri.

39. Bryson-Cahn C, Duchin J, Makarewicz VA, Kay M, Rietberg K, Napolitano N, et al. A novel approach for a novel pathogen: Using a home assessment team to evaluate patients for COVID-19. Clin Infect Dis 2020;71:2211-4.

40. T.C. Sağlık Bakanlığı. COVID-19 - Yeni Koronavirüs Hastalığı. Last Accessed Date: 11.05.2020. Available from: https://covid19bilgi. saglik.gov.tr/tr/.

41. Ranney ML, Griffeth V, Jha AK. Critical supply shortages - the need for ventilators and personal protective equipment during the Covid-19 pandemic. N Engl J Med 2020;382:41.

42. Ishack S, Lipner SR. Applications of 3D printing technology to address COVID-19-related supply shortages. Am J Med 2020;133:771-3. 